\title{
Applications of Malaysia Deposit Insurance Corporation (MDIC) To Takaful Operators: An Analysis from the Shariah Advisors' Perspective
}

\author{
Nurdianawati Irwani Abdullah*, Djafri Fares \\ Kulliyah of Economics and Management sciences International Islamic University Malaysia (IIUM), Malaysia \\ *irwani@iium.edu.my
}

\begin{abstract}
The global takaful market is estimated by market analysts to reach a premium of U.S. \$ 12.5 billion by 2015. Malaysia is considered the second largest takaful in the world with total asset of US\$ 3.2 billion. One of the new innovations of takaful and insurance in Malaysia is Perbadanan Insurance Deposit Malaysia (PIDM) which is also known internationally as the Malaysia Deposit Insurance Corporation (MDIC). The role of MDIC is to provide protection to owners of takaful certificate and to ensure the stability and confidence in the market by protecting policy holder (takaful certificate). Therefore, this study investigates the extent to which MDIC is relevant to takaful operators. Personal interviews are carried out with shariah advisers of takaful operators to deduce the actual practice, the ideal role and to gain access to the field of MDIC and its implications in Malaysia. The findings of this research indicate that MDIC is relevant to takaful operators and part of the regulations that should be supported and encouraged. Furthermore, the study also found that shariah advisers suggest Wakalah bi ajr as an alternative of kafalah-bi al-ajr by shifting the scheme to tabarru'model. In addition, the study found that the contribution paid should be charged to the participants' fund; this is because the protection provided by MDIC is for the fund that belongs to the participants and takaful operators deemed to be wakeel (agent) only.
\end{abstract}

Key words: PIDM, MDIC, kafalah-bi al-ajr, Tabarru'model

\section{Introduction}

Insurance is a mechanism whereby individual or business enterprises by paying out contribution (Premium) transfer some of the ambiguity of the risk to insurer. Overall, the concept of Insurance is an arrangement between the insurer and individuals or businesses to mutually help one another in the event of a contingent loss to any of the member(s) (Qureshi, 2011). An alternative model of conventional insurance is takaful which constitute an integral part of Islamic financial system. The idea of shariah-compliant insurance popularly known as Takaful was first introduced in Sudan in 1979. This was motivated by the growing needs of Muslim consumers for an insurance protection that is compatible with Shariah principles (Qureshi, 2011). Abdul Wahab, Lewis and Hassan, (2007) stated that, takaful operators and products offered in more than 22 countries. It has also been noticed that the Islamic insurance sector or takaful has expanded in many major markets and in Muslim dominated countries around the world. Malaysia is the second largest takaful market in the world as its total assets of US $\$ 3.2$ billion dominated $26 \%$ of total global takaful assets in 2009 (Bank Negara Malaysia, 2011). Mohd Razif (2011) noted a robust expansion of takaful in Malaysia in which average annual growth rate of total assets and contributions increased from 20 percent to 26 percent from the period of 2004 through 2009. One of the new innovations of takaful and insurance in Malaysia is Takaful and Insurance Benefits Protection Scheme (TIPS) which was implemented on 31 December 2010. TIPS are the latest financial consumer protection scheme to be administered by Perbadanan Insurance Deposit Malaysia (PIDM). Overall, PIDM which is also known internationally as the "Malaysia Deposit Insurance Corporation" (MDIC) is a Government agency established in 2005 under Akta Perbadanan Insurance Deposit Malaysia (PIDM Act) to administer the national deposit insurance system aimed at protecting depositors. On 31 December 2010, PIDM's role was expanded to include administration of TIPS to provide protection to owners of takaful certificates and insurance policies. Hence, PIDM come up to administer the deposit insurance system and Takaful and Insurance Benefits Protection Scheme (TIPS). (Perbadanan Insurance Deposit Malaysia, 2012). Accordingly, the primary objective of this research is to observe the perceptions of shariah advisers of takaful operators on the impact of the introduction of Malaysia Deposit Insurance Corporation (MDIC) towards takaful operators. This study is guided by the following research questions: To what extent is 
MDIC relevant to takaful operators? What are the impacts of the introduction of Malaysia Deposit Insurance Corporation (MDIC) on takaful operators? What are the perceptions of Shariah advisers towards the applications of Malaysia Deposit Insurance Corporation (MDIC)? Since this study intends to deeply explore and investigate the experiences of shariah advisers of takaful operators, it would assist the Malaysian government in making decision with regards to the development of the takaful industry. In other words, the study is notably significant and timely, as the Malaysia Deposit Insurance Corporation (MDIC) started not long ago in 2005 for banks and expands their rule to takaful operators at the end of 2010. Thus, the result of this study is expected to contribute to the financial system development and policy making in Malaysia.

\section{Literature Review}

Many researchers have contributed to the literature regarding the issue of Deposit Insurance Scheme (DIS) such as Garcia, (1999); Dermirguc-kunt and Kane (2002); Blair, Carns and Kushmeider (2006); Chiang, Wu and Yu (2007) ; Safakli, and Guryay (2007); Chu, (2011). Most of these studies focused on the efficiency of the introduction of Deposit Insurance Corporation (or scheme) in maintaining bank stability especially in the developed countries such as the United States and European countries. However, there is very narrow scope on the studies that have been done on the field of Malaysia Deposit Insurance Corporation (MDIC). For instance, (Ng, Lim, and Tan. 2010), in their work "Deposit Insurance and Bank Risks, in Malaysia" investigated the effect of the introduction of Deposit Insurance scheme on bank risks given that a proper risk management is vital to maximize shareholders' return and to protect the interests of all stakeholders. Ng et al., (2010) noted that Deposit Insurance Scheme (DIS) may increase bank stability by reducing the possibility of banks runs. In contrast, bank in taking excessive risks given the protection of deposit insurance. Furthermore, they noted that the premium that the banks pay for the service do not vary with risk. Thus, it is unfair to charge the same to all banks regardless of the individual unique risk associated with each operation. In addition, the study of (Rasiah and kim, 2011) have examined the rationale of deposit insurance for commercial bank in Malaysia, and how regulatory conditions and reforms can also help support a stable environment. Having said that, most of the studies that have been conducted in this area of research, represented findings that explicit deposit insurance schemes have mixed effect on banks risk (Garcai. 1999; Demirguc-kunt and Kane. 2002; Ng et al., 2010). Another study that has been done on the field of MDIC was conducted by (Mohd Noor and Haroun, 2011). The study investigated the validity of an applied shariah instrument of al-kafalah bi al-ajr (charging fee for guarantee), where the premium paid by the member institutions to MDIC are considered as ujrah or fees for service (protection). Therefore, (Mohd Noor and Haroun, 2011) revealed that the structure of al-kafalah bi al-ajr contract perhaps needs re-examination since it could be similar to conventional insurance. This is because the transaction is based on sale and purchase where the ownership is mutually exchanged and transferred. Thus, the relationship between the participants and takaful operators is clearly Mu'awadhah contract (commercial exchange), where the insured will buy a protection from the insurer, and the insurer will own the payment of all the accumulated premium and surplus.

Mohd Noor and Haroun (2011) mentioned that the guarantee and the protection come from the risk fund performed by takaful operators on behalf of the fund. Therefore, the takaful contractual relation clearly defines the position of the operators which is a Wakeel (agent) appointed by the participants to manage their fund, conduct a prudent underwriting and payment of claims. Moreover, Mohd Noor and Haroun (2011) noted that the protection premium that paid by takaful operators to PIDM from its own account which is reflected in the balance sheet as expenses, would amount to issuing guarantee. Hence, the pool of premium (tabarru' fund) should be treated independently with separate financial statement and the cost of protection should be borne by the fund itself. Malaysia Insurance Online News (2011) mentioned that insurance and takaful operators "industry players" move from Insurance levy to PIDM premium. Moreover, the Malaysia Insurance Online News stated that: "The premium to be paid to PIDM is in fact related to those levies that "industry players" used to pay to the Bank Negara Malaysia (BNM) before. The levy ${ }^{1}$ imposed then was $0.25 \%$ of the gross premium charged by the industry players". Furthermore, the Malaysia Insurance News noted that the main issue that may face the implementation of PIDM is the problem of coordination between industry

${ }^{1}$ Charge for the Insurance Guarantee Scheme Fund (IGSF) that was imposed to help safeguard policyholder in case an industry player goes down. 
players, whereby some players are adopting their date for implementation whereas some industries were not aware of what is going on except for the fact that the company needs to pay some premiums to PIDM for insurance cover provided. Hence, this study primarily aims to address that gap in the literature by investigating the extent to which MDIC is relevant to takaful operators by analyzing the perceptions of shariah advisers of takaful operators. Thus, the study will focus on the application of Malaysia Deposit Insurance Corporation (MDIC) to takaful operators.

\section{Methodology}

As Malaysia Deposit Insurance Corporation (MDIC) is considered a new undescribed research area, certain flexibility is needed to answer the research questions. Thus, qualitative research appears to be an appropriate choice to answer the research questions and to provide an overall picture on the role of MDIC and its implications on takaful operators in Malaysia. Creswell (2008) mentioned that qualitative research is an exploration in which little is known about the problem. Moreover, (Creswell, 1994) mentioned that qualitative researches are interested in Meaning, typically rich with detail and insights into participants' experiences and their structures of the world. Therefore, the researcher conducted interview with shariah advisers of takaful operators and observed their opinions and perceptions on the applications of Malaysia Deposit Insurance Corporation. These individuals were selected mainly due to their experience and involvement in various areas related to shariah ruling for takaful companies. Thus, they may be able to provide an overall picture of the performance of PIDM and its implications toward takaful companies in Malaysia. Moreover, most participants have the knowledge about the phenomenon of the issues being explored. As a result, the sampling of the respondents will be considered as purposive sampling. Data was collected for this question through interviews, and reviews of available documents. Participants were advised that the interviews were confidential and would be audiotaped to allow for transcription at a later time and to achieve general information that allow the data to be read. The researcher listened to the audiotapes following the interviews and transcribed each interview verbatim. This technique is applied to make sense out of the text data, such as text segment or image segment (Creswell, 2008). After that, the theme or concept of the interview is identified. Once the themes are revised and clarified, the last step is to analyze the data. King and Horrocks (2010) divide the process of thematic analysis into three stages. The first step starts with descriptive coding to identify from the transcript data the relevant materials that are likely to be helpful in addressing the research question. The second step is to define codes that go beyond describing relevant features of participants' accounts and focus more on the interpretation of their meaning. The last step is to identify a number of overarching themes that characterize key concept of the analysis.

Trustworthiness of the Research: The concept of validity determines whether the research truly measures that which it was intended to measure or how truthful the research results are. Reliability refers to the stability and consistency of a particular measure or instrument. It ensures consistent measurement across time and the variations items in the instrument (Creswell, 2008). Guba and Lincoln (1985) conceptualized a new dimension to determine the authenticity of qualitative paradigm and they refer to it as trustworthiness criteria. They also came up with the following techniques for meeting those criteria:

- Credibility: It is used by qualitative researcher to demonstrate that the findings of the research are credible to their population. Other approaches to credibility include; member checking and peer reviewing. Therefore, all the aspects of this study were discussed with different experts of takaful operators.

- Transferability: Although, the findings of qualitative are not directly transferable from one context to the other, the transferability of findings in qualitative always depend on the similarity in the context of the research. However, one of the means to carry out the similarity of context was the method known as thick description. Therefore, in order to make this research transferable to other settings, a thick description of the time, the place, the context, and the activities involved at each stage of this research will be explained in detail.

- Dependability: To enhance the dependability of this study, the method involved in the data collection and analysis will be given to an expert in the field of this study to review it and make necessary comments on it.

- Conformability: It is also known as external reliability; it involves an attempt to trace the evaluation conclusions back to the original source. It is similar to the concept of reliability in quantitative 
research, with the point that another researcher should be able to examine the data, confirm, modify, or reject the interpretation of the first researcher. Therefore, the coded main ideas of this research were given to one expert in the field of this study to ascertain the level of the agreement in the coding of the main ideas and the themes generated.

\section{Results and Discussion}

Data for this study was composed of a total of 5 individual interviews of Shariah adviser of takaful operators. All of the five participants in this study were male and had worked for at least four years in their respective fields. Besides that, the companies were selected according to their reputation as well as their performance in the recent years. The identity of the respondents was kept confidential by assigning pseudonyms of P1 for Participant 1, P2 for Participant 2, and so on. The table below provided more information on the demographics of the study participants.

Table 1: Demographic information for respondent

\begin{tabular}{lllllll}
\hline & CIMB & HSBC & MAA & PRUD & ETIQA & Mean \\
\hline Age & 40 & 39 & 40 & 45 & 43 & 41.4 \\
Experience & 5 & 7 & 6 & 6 & 4 & 5.6 \\
Gender & Male & Male & Male & Male & Male & $/$ \\
\hline
\end{tabular}

The interpretation of findings is organized along the study's research questions and sub questions, the themes that emerged through the participants' responses and the applicability of several theories presented in the literature review, namely, safety net \& stability, treatment of the contribution paid, coverage, MDIC Vs RE-TAKAFUL, opinions on kafalah-bi al-ajr, and shariah compliant.

Safety net \& Stability: The current study found out that, all participants reported that PIDM is relevant to takaful operators and to the industry as a whole. Moreover, most participants perceived the implementation of MDIC positively and as a part of the regulations that should be supported and encouraged. Besides that all participants stated that MDIC is trying to ensure the stability and confidence in the market by protecting policy holders (takaful certificate). Respondents have the following to say: "I believe at the perspective of the takaful operators, it does not really relevant to the business. This is just my opinion but to the interest of the policy holder at large...especially when the takaful operators collapse (P1)". "The role of PIDM is more towards risk management and also when it comes to winding up of the company... The objective of PIDM is very noble... meaning that, to protect the industry as whole (Islamic finance as takaful operates as whole) (P2)". "Additional protection for the participants should be welcomed and should be encouraged especially since this is government initiative (P3)". "The most important thing is to protect participants but at the same time this also to protect takaful operators (P4)". Another respondent said: "It is related to insure confidence in the market, safeguard the interest of the member and the participants from losses in case of takaful operators' collapse (P5)". Similar to this finding, (Arshad, 2011) noted that PIDM comes out to provide protection against the loss of part or all of takaful or insurance benefits for which an insurer member is liable, provide incentives for sound risk management in the financial system, and promote or contribute to the stability of the financial system.

The treatment of the contribution paid: The study found out that there were controversies among takaful operators on the treatment of the contribution paid to PIDM. Nevertheless, most of the participants suggested that the contribution paid should be from participants' fund; this is because the protection provided by PIDM for the fund that belongs to the participants and takaful operators deemed to be wakeel only. Respondents have these to say: "It is from the participants' fund, for sure. This is because the operators will not pay out of their own pocket... (P1)". "I think from the participants risk fund, because the most important thing for the benefit of participants and takaful operator is just a Wakeel (Ajir) (P4)". "So basically the fees should be charged to the risk fund which is the participants because you are securing their fund... (P5)". Therefore, the findings of the current study are consistent with those of (Mohd Noor and Haroun, 2011) who suggest that the premium should be borne by participants risk fund which are realized by takaful operators. Therefore the protection will come from the risk fund which is managed by takaful operators on behalf of the fund. Thus, the takaful operators will be considered as wakeel (agent) appointed by the participants to manage their fund 
and not to give guarantee. Besides that, the statement of the financial position of CIMB, HSBC, MAA, ETIQA, and PRUDENTIAL revealed that there are no consensus between takaful operators on the treatment of the levy paid by Takaful operators to PIDM. To elaborate, the statement of financial position of CIMB AVIVA Assurance Berhad (Appendix I) reported in the annual report of 31 December 2011 reveals clearly that the PIDM levy is classified under management expenses with other type of operating cost with a total amount of RM 528,000. On the other hand, in the income statement and expenditure of HSBC Amanah, MAA takaful, and ETIQA Takaful Berhad (Appendix I), the statements show that all takaful operators do not clarify PIDM levy; instead they show the total amount of expenses which amounted to RM 654,282, RM 784,511, and RM 14,562.000 respectively. In addition, the statement of financial position of PRUDENTIAL Takaful shows that the management expenses are classified under shareholders' fund with a total amount of RM 112,223.000. Therefore, it is obvious that there is no consensus between takaful operators on the treatment of the levy paid by Takaful operators to PIDM. As a result, the differences between takaful operators may feature some limitations, including comparability of financial data and the need to look beyond ratios. Hence, takaful operators should have the same treatment of the premium paid to MDIC.

Coverage: The study found out that most of the participants argued that the protection provided by MDIC was not high and would not encourage Takaful operators to take excessive risk. I don't think this will occur...Through my experience BNM has very strike regulations and well governed rules (P4). I don't think so because there are traditions in the business, there is some risks management, standards and there is a procedure for that. (P5). I don't think so because this protection against the failure of T0 and does not benefit them directly but to the participants (P3). However, MDIC is still a new policy which was introduced in end of 2010. Thus, we need to collect data to see if the protection provided is excessive or not. Consequently, this would be deemed an important issue for future research.

MDIC Vs RETAKAFUL: In response to this question, participants discussed their views and perceptions on the main differences between Re-takaful and MDIC in respect to the risk management. Most of the participants seemed to be confused about the differences between Re-takaful and MDIC. Therefore, the researcher adds some clarification by one more question which is: why PIDM since there is Re-takaful? Accordingly, the following table Compares and contrasts between Re-takaful and MDIC

Table 2: Comparison between Re-takaful and MDIC

\begin{tabular}{|c|c|c|}
\hline & MDIC & RE-TAKAFUL \\
\hline Protection & $\begin{array}{l}\text { Promote or contribute to the stability of the } \\
\text { financial system as a whole and make the } \\
\text { financial transaction more efficient } \\
\text { MDIC is concerned with protecting the } \\
\text { participants and the industry as a whole } \\
\text { provide protection to owners of takaful } \\
\text { certificates and insurance policies from the } \\
\text { loss of their eligible takaful or insurance } \\
\text { benefits in the unlikely event of an insurer } \\
\text { member failure }\end{array}$ & $\begin{array}{l}\text { protect the financial stability of takaful } \\
\text { companies from adverse underwriting } \\
\text { results } \\
\text { Re-takaful is more on individual dealing to } \\
\text { cap the risk and ensure that Takaful funds } \\
\text { are managed to meet the indemnity } \\
\text { obligations } \\
\text { Re-takaful does not provide protection to } \\
\text { owners of takaful certificate and insurance } \\
\text { policies if any takaful operator or } \\
\text { insurance company collapses. }\end{array}$ \\
\hline Membership & $\begin{array}{l}\text { All takaful operators and insurance } \\
\text { companies are member institutions of MDIC } \\
\text { Membership in MDIC is compulsory as } \\
\text { provided under Akta Perbadanan Insurants } \\
\text { Deposit Malaysia (PIDM) }\end{array}$ & $\begin{array}{l}\text { Re-takaful operators and Reinsurance } \\
\text { companies are not member institutions of } \\
\text { MDIC }\end{array}$ \\
\hline $\begin{array}{l}\text { Rules \& } \\
\text { Regulation }\end{array}$ & $\begin{array}{l}\text { MDIC is a government agency step in to put } \\
\text { standard parameters and regulation to the } \\
\text { financial industry as a whole. }\end{array}$ & $\begin{array}{l}\text { Re-takaful is an Initiative Company that is } \\
\text { very subjective from one institution to } \\
\text { another and there are no common } \\
\text { parameters and standards imposed by the } \\
\text { regulators. }\end{array}$ \\
\hline Business & $\begin{array}{l}\text { MDIC is not really relevant to business to get } \\
\text { profit. }\end{array}$ & $\begin{array}{l}\text { Re-takaful is more relevant to business and } \\
\text { investment oriented in nature }\end{array}$ \\
\hline
\end{tabular}


Opinions on kafalah bi al-ajr: Most respondents agreed that there are debates among scholars on the rule of kafalah-bi al-ajr. The majority of participants agreed that the general rule of kafalah-bi al-ajr is to offer guarantee free of charge since kafalah falls under the category of aqd al-tabarru' (donation contract). In other words, kafalah-bi al-ajr is gratuitous in nature and should not be commercialized. Moreover, they agreed that the scheme of kafalah has been shifted to different circumstances and to different concept to suit the commercial transaction and due to the needs of the community. Besides that, participants noted that we should explore other option that is not controversial and which is more Islamic and more in the line with the scheme of takaful. In relation to this, a respondent reported: if you have any shariah problem with that, you shift the scheme to tabarru'. It will be pool of tabarru' and it will be kind of takaful and therefore the PIDM will be taking the position of Re-takaful (P5). Another respondent emphasized his point: the best option is Commitment to donate (التزام بالتبرع)" tabarru". I mean from the participant side Commitment to donate but from PIDM side is wakalah...(P4). As a consequence, participants stated that Wakalah bi ajr can be used instead of kafalah by shifting the scheme to tabarru' (donation) contract. This view is similar to AAOIFI standard where there is no charge imposed and the scheme will be based on tabarru' (donation) not with fee imposed by the guarantor, where it becomes a contract of commercial exchange (mu'awadhah) which is not allowed. This finding further support the idea of (Mohd Noor and Haroun, 2011 and Al Qaradaghi, 2009) who suggests that the possible alternative for kafalah model is takaful tabarru' model. Besides that Islamic insurance "Takaful operators" is considered as an agent "wakeel" appointed by the participants to manage their fund and should not give any guarantee. However, some of the issues emerging from this finding relate specifically to the fact that PIDM will be taking the position of Re-takaful if they shift the scheme to donation contract "tabarru'contract". Therefore, this may be considered double taxation on the fund from the side of PIDM and Re-takaful companies. Accordingly, the following figure shows the proposition structure of PIDM whereby the premium should be from the participants' fund and the scheme will be based on tabarru' model (donation):

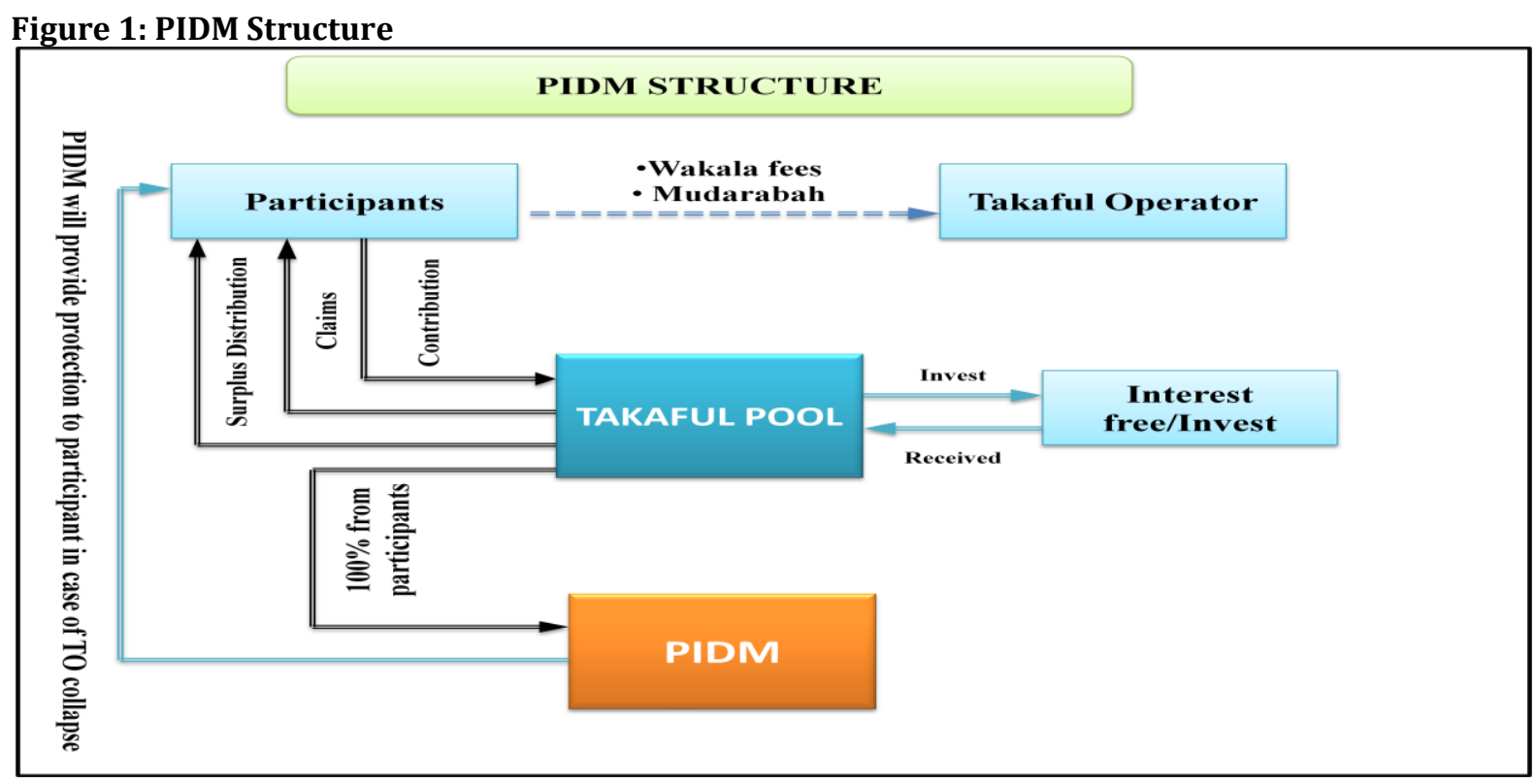

\section{According to Figure 1:}

- Takaful companies can use two main operational models for Islamic Insurance, such as Wakala and Mudharaba.

- Participants mutually agree to contribute into takaful pool as donation (Tabarru') and formulate a pool of money.

- The pool of money will be considered as juristic person that has an independent legal personality from which the damage suffered by one who subscribes is compensated according to the regulations and policies 
- The pool of money fund (takaful Pool) shall be managed by a board of selected policyholders or by Shareholding Company.

- The pool of money fund (takaful Pool) can be invested to earn Halal profit that is based on shariah compliant investments.

- The amount of profit earned is then included in money pool (takaful Pool) and then distributed among the participants.

- Certain proportions of the contributions are set aside to provide financial assistants to other participant in the event of disaster, losses, and claims.

- Certain proportions of the contributions paid by the participants are set aside to pay the levy for PIDM in full (100\%)

- PIDM protects owners of takaful certificates and insurance policies in the case of an insurer member fail.

Shariah compliant: The majority of Participants noted that the objective of PIDM is to protect the owners of policy holder from the loss of their eligible takaful or insurance benefits and also towards precaution measurements of the financial system and make it more robust and resilient. But as far as shariah compliance is concerned, there are some issues and controversies among shariah advisers that perhaps need reconsideration and reassessment to be shariah compliant. Respondents have these to say: This is not yet fully shariah compliant because of these issues of kafalah bi al-ajr (P4). I don't think that is compliant because it is conventional company... (P2). I believe that it is still controversial; I cannot say that $100 \%$ shariah compliant ... (P3)

\section{Conclusion and Recommendations}

Based on the conducted study, the researchers conclude the following:

- PIDM is relevant to Takaful operators and to the industry as a whole.

- The levy paid to PIDM should come from the participants' fund; this is because the protection provided by PIDM is for the fund that belongs to the participants while takaful operators deemed to be wakeel (agent) only.

- Takaful operators should have the same accounting method for the levy paid to MDIC to allow comparisons between the statements of financial position of takaful operators.

- Takaful operators might shift the scheme of kafalah to tabarru' contract taking into consideration the position of Re-takaful companies.

- the structure of PIDM is not fully shariah compliant and perhaps need reconsideration to be shariah compliant

Moreover, this study has provided better understanding of takaful especially regarding their roles, functions, and status of Malaysia Deposit Insurance Corporation (MDIC) in line with the takaful operators. In other words, this study is expected to assist the Malaysian government in making decision with regards to the development of the takaful industry. Thus, the results of this study are expected to contribute to the financial system development and policy making in Malaysia.

\section{References}

Abdul-Wahab, A., Lewis, M. M. \& Hassan, M. K. (2007). Islamic Takaful: Business Models, Shariah Concerns, and Proposed Solutions. Published online in Wiley InterScience. International Business Review, 49(3) 371-396

Al Qaradaghi, A. M. (2009). Ta'amine el-Dayn wa el-Thamane. Kurdistan, IRAQ.

Blair, C. E., Carns, F. \& Kushmeider, R. M. (2006). Instituting a Deposit Insurance System: Why? How? Journal of Banking Regulation, 8, 4-19.

Chiang, T. F., Wu, E. C. \& Yu, M. T. (2007). Premium Setting and Bank Behavior in a Voluntary Deposit Insurance Scheme. Springer Science + Business Media, Rev Quant Finan ACC, 29, 205-222.

Chu, K. H. (2011). Deposit Insurance and Banking Stability. Cato Journal, 31(1).

Creswell, J. W. (1994). Research Design. Qualitative and Quantitative Approaches. London: Sage Publication 
Creswell, J. W. (2008). Educational Research, Planning, Conducting, and Evaluating Quantitative and Qualitative Research. Merrill Prentice Hall.

Demirguc-Kunt, A. \& Kane, E. J. (2002). Deposit Insurance Around the Global: Where Does it Work? Journal of Economic Perspective, 16(2), 175-195.

Garcia, G. G. H. (1999). Deposit Insurance: A Survey of Actual and Best Practices. IMF Working Paper. No WP/99/54, International Monetary Fund.

King, N. \& Horrocks, C. (2010). Interviews in Qualitative Research. Los Angeles: Sage publication.

Lincoln, Y. S. \& Guba, E. G. (1985). Naturalistic Inquiry. London: Sage Publication

Mohd-Noor, A. \& Haroun, M. (2011). Charging Fee for Guarantee (al-kafalah bi al-ajr) and its Application by Deposit Insurance Corporation Malaysia. (PIDM) for Takaful Benefits Protection Scheme. $8^{\text {th }}$ International Conference on Islamic Economics and Finance

Mohd-Razif, B. A. K. (2011). Our Strategy Towards Developing A Progressive Takaful Industry, Keynote Speaker at the official launch of AIA AFG Takaful Bhd, Kuala Lumpur, 28 January 2011. Retrieved from http://www.bnm.gov.my/index.php?ch=9\&pg=15\&ac=395, 23 January 2012.

Ng, T. H., Lim, Y. N. \& Tan, L. N. (2010). Deposit Insurance and Bank Risks: The case of Malaysia. European Journal of Economics, Finance and Administrative Sciences, 18(1).

Qureshi, A. A. (2011). Analyzing the Sharia'h compliant issues currently faced by Islamic Insurance. Journal of Contemporary Research in Business, 3(5).

Rasiah, D. \& Kim, P. K. (2011). The Rational of Deposit Insurance in Malaysia and How Regulatory Conditions and Reforms can also help Support a Stable Environment. European Journal of Economics, Finance and Administrative Sciences, 33(1).

Safakli, O. V. \& Guryay, E. (2007). A Research on Designing an Effective Deposit Insurance Scheme for TRNC with Particular Emphasis on Public Awareness. International Research Journal of Finance and Economics, 1, 1450-2887

http://www.pidm.gov.my/

http://www.bnm.gov.my/

http://www.malaysiainsurance.info/

\section{APPENDIX I}

The Statement of Financial Position HSBC AMMANA TAKAFUL

- 17 Statement of income and expenditure For the year ended 31 December 2011

\begin{tabular}{|c|c|c|c|c|c|c|c|c|c|}
\hline & Note & $\begin{array}{l}\text { North } \\
\text { East Asian } \\
\text { Tigers } \\
\text { (N.EA.T.) } \\
\text { portfolio } \\
\text { MYR }\end{array}$ & $\begin{array}{l}\text { The } \\
\text { Wellness } \\
\text { portfolio } \\
\text { MYR }\end{array}$ & $\begin{array}{l}\text { Essentials } \\
\text { porttolio } \\
\text { MYR }\end{array}$ & $\begin{array}{l}\text { North } \\
\text { East Asian } \\
\text { Tigers 2 } \\
\text { (N.EA.T2) } \\
\text { portiolio } \\
\text { MYR }\end{array}$ & $\begin{array}{l}\text { Rising } \\
\text { Phoenix } \\
\text { portlolio } \\
\text { MYR }\end{array}$ & $\begin{array}{l}\text { Fying } \\
\text { Dragon } \\
\text { portiolio } \\
\text { MYR }\end{array}$ & $\begin{array}{l}\text { HSBC } \\
\text { Amanah } \\
\text { Iffeselect } \\
\text { Fixed } \\
\text { Income } \\
\text { Fund } \\
\text { MYR }\end{array}$ & $\begin{array}{l}\text { HSBC } \\
\text { Amanah } \\
\text { LifeSelect } \\
\text { Equity } \\
\text { Fund } \\
\text { MYR }\end{array}$ \\
\hline $\begin{array}{l}2011 \\
\text { Investment income } \\
\text { Profit from deposits with } \\
\text { financial institutions } \\
\text { Profit from corporate debt securities } \\
\text { Diwidend income } \\
\text { Accretion of discounts } \\
\text { Unrealised capital gain on investments } \\
\text { Gain on disposal of investments }\end{array}$ & & $\begin{array}{l}- \\
- \\
- \\
-\end{array}$ & $\begin{array}{l}- \\
- \\
- \\
-\end{array}$ & $\begin{array}{l}\text { - } \\
\text { - } \\
\text { - } \\
\text { - }\end{array}$ & i- & $\begin{array}{r}. \\
506,310 \\
-\end{array}$ & $\begin{array}{l}- \\
. \\
. \\
.\end{array}$ & $\begin{array}{r}309,963 \\
1,140,540 \\
- \\
156,365 \\
184,894 \\
-\end{array}$ & $\begin{array}{r}289,707 \\
1,360,307 \\
- \\
595,145\end{array}$ \\
\hline Total income & & - & - & - & 953,861 & 506,310 & - & $1,791,752$ & $2,245,159$ \\
\hline $\begin{array}{l}\text { Unreal ised capital loss on investments } \\
\text { Loss on disposal of investments } \\
\text { Other outgo }\end{array}$ & & - & - & 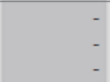 & (2,382) & (37,681) & $\begin{array}{r}{[898,889]} \\
(114,922]\end{array}$ & (654282) & $\begin{array}{l}(2,223,955) \\
(1,181,667)\end{array}$ \\
\hline Total outgo & & - & - & - & (2,382) & {$[37,681)$} & $(1,013,811)$ & (654282) & $(3,405,622)$ \\
\hline $\begin{array}{l}\text { Income/(Loss) before taxation } \\
\text { Taxation }\end{array}$ & & - & - & - & 951,479 & 468,629 & $\begin{array}{r}{[1,013,811)} \\
-\end{array}$ & $\begin{array}{r}1,137,470 \\
{[154,998)}\end{array}$ & $\begin{array}{r}(1,160,463) \\
143,132\end{array}$ \\
\hline $\begin{array}{l}\text { Income/(Loss) after taxation } \\
\text { Generated income/loss] brought forward } \\
\text { Transfer to participants' fund }\end{array}$ & & - & - & $\overline{-}-$ & $\begin{array}{r}951,479 \\
5,232,684 \\
(6,184,163)\end{array}$ & $\begin{array}{r}468,629 \\
(2,537,800) \\
-\end{array}$ & $\begin{array}{r}(1,013,811) \\
(200,366) \\
-\end{array}$ & $\begin{array}{r}982,472 \\
240,976 \\
-\end{array}$ & $\begin{array}{r}(1,017,331) \\
3,164,060 \\
-\end{array}$ \\
\hline $\begin{array}{l}\text { Generated income/loss) } \\
\text { carried forward }\end{array}$ & & & & - & & $(2,069,171)$ & $(1,214,177)$ & 1223,448 & $2,147,529$ \\
\hline
\end{tabular}


MAA TAKAFUL

\section{STATEMENT OF INCOME AND EXPENDITURE}

FOR THE FINANCIALL YEAR ENDED 31 DECEMBER: 2011 (continued)

INCOME

Net inwestment incame

Profit income

Dividend income

Profit on disposal

Equity Securities

Unrealised capital gain

Equity Securities

TOTAL INCOME

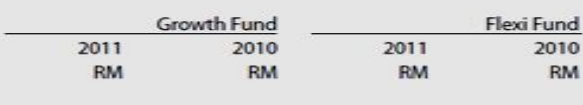

\begin{tabular}{rrrr}
414,985 & 153,073 & 153,608 & 14,090 \\
$1,117,331$ & 827,906 & 225,990 & 10,358 \\
$3,299,638$ & $2,228,216$ & 65,281 & 43,794 \\
- & $4,490,548$ & 616,890 & 238,682 \\
\cline { 2 - 2 } & 7,6331,959,743 & $1,061,769$ & 306,924 \\
\hline
\end{tabular}

OUTGO

Management fees and administrative

expensers

$\begin{array}{lll}(784,511) & (5,49,240) & (176,789)\end{array}$

Unrealised capital loss

Equity Securities

[287,689)

TOTAL OUTGO

$\overline{(1,072,200)} \frac{1}{(5,49,240)} \stackrel{-}{(176,789)}$

\section{ETIQA INSURANCE BERHAD}

(Incorporated in Malaysia)

29. MANAGEMENT EXPENSES

\begin{tabular}{|c|c|c|}
\hline & $\begin{array}{r}1.7 .2011 \text { to } \\
31.12 .2011 \\
\text { RM'000 }\end{array}$ & $\begin{array}{r}1.7 .2010 \text { to } \\
30.6 .2011 \\
\text { RM'}^{\prime} 000\end{array}$ \\
\hline Employee benefits expense (a) & 68,878 & 104,238 \\
\hline Directors' remuneration (b) & 667 & 1,215 \\
\hline \multicolumn{3}{|l|}{ Auditors' remuneration: } \\
\hline - statutory audits & 765 & 759 \\
\hline - overprovision in prior year & (33) & (99) \\
\hline - other services & 32 & 166 \\
\hline Amortisation of intangible assets & 1,976 & 129 \\
\hline \multicolumn{3}{|l|}{ Amortisation of prepaid land lease } \\
\hline payments & 152 & 252 \\
\hline Bank charges & 3,293 & 4,196 \\
\hline Depreciation of property, plant and equipment & 7,955 & 6,762 \\
\hline Fund management fees & 8,698 & 15,187 \\
\hline Other management fees & 546 & 1,283 \\
\hline Professional fees & 7,707 & 17,792 \\
\hline Rental of offices/premises & 1,935 & 5,506 \\
\hline Electronic data processing expenses & 263 & 11,890 \\
\hline Outsourcing services & 8,879 & 14,552 \\
\hline Postage \& stamp duties & 2,375 & 5,606 \\
\hline Printing \& stationery & 1,553 & 2,797 \\
\hline Promotional and marketing cost & 8,092 & 10,740 \\
\hline Training expenses & 1,568 & 3,251 \\
\hline Utilities, assessment and maintenance & 1,097 & 8,555 \\
\hline Entertainment & 1,127 & 2,780 \\
\hline Travelling expenses & 2,234 & 3,919 \\
\hline Office facilities expenses & 1,025 & 2,261 \\
\hline Legal fees & 965 & 744 \\
\hline Other expenses & 14,562 & 8,330 \\
\hline TOTAL MANAGEMENT EXPENSES & 146,311 & 232,811 \\
\hline
\end{tabular}




\section{ETIQA TAKAFUL}

PRUDENTIAL TAKAFUL CIMB AVIVA TAKAFUL BERHAD

20 MANAGEMENT EXPENSES

$\begin{array}{lrr} & \frac{2011}{2010} \\ \text { Employee benefits expense (note 20(a)) } & 27,778 & 25,997 \\ \text { Directors' fees and allowance (note 20(b)) } & 240 & 194 \\ \text { Auditors' remuneration: } & 431 & 270 \\ \text { - current financial year } & 214 & 89 \\ \text { - under accrual in respect of prior financial year } & 1,936 & 10,321 \\ \text { Electronic data processing expenses } & 2,650 & 941 \\ \text { Advertising expenses } & 4,113 & 3,872 \\ \text { Depreciation of property and equipment (note 3) } & 2,567 & 243 \\ \text { Write off of property and equipment } & 147 & 47 \\ \text { Rental expenses } & 528 & 1,098 \\ \text { PIDM levy } & 1,142 & 9,894 \\ \text { Telephone and postage expenses } & 10,049 & 52,966 \\ \text { Others } & -51,795 & = \\ & = & \end{array}$

Statement of comprehensive income for the year ended 31 December 2011

Operating revenue

Shareholders" fund:

Wakalah fee

Investment income

Realised gains and losses

Fair value gains and losses

Management expenses

Commission paid

Other operating income

Increase in provision for wakalah fee

Profit before taxation

Tax expense

Zakat

Net profit/ Total comprehensive income for the year
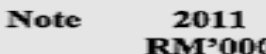

2010

RM'000

RM'000

17

541,902

408,328

210,668

7,408

1,107

$(112,223)$

(145,831)

71,750

$(6,216)$

10

25

$$
\begin{array}{r}
27,632 \\
(7,590) \\
(378)
\end{array}
$$

19,664
170,907

2,281

1,414

886

$(86,883)$

(118,314)

59,119

$(9,601)$

19,809

$(5,740)$

(136)

13,933 